\title{
Evaluasi Program Bantuan Pelaksanaan Teaching Factory di SMK Jakarta Pusat 1
}

\author{
Agus Ramdan Rukmana ${ }^{1}$, Andita Rahmawati ${ }^{2}$, Jamas Sari Murni ${ }^{3}$, Via Halida Adzani ${ }^{4}$ \\ Sekolah Pascasarjana, Universitas Muhammadiyah Prof. DR. HAMKA \\ email: agsrmdn@gmail.com ${ }^{1}$,anditarahmah9@gmail.com ${ }^{2}, \underline{\text { sari.murni48@gmail.com }}$, \\ halidavia36@gmail.com ${ }^{4}$
}

Received: 26 April 2021; Revised: 16 July 2021; Accepted: 13 August 2021

DOI: http://dx.doi.org/10.37905/aksara.7.3.959-966.2021

\begin{abstract}
Abstrak
Teaching Factory merupakan suatu pendekatan dalam dunia pendidikan vokasi dimana dirancang proses pembelajaran seperti dunia kerja bertujuan memodernisasi proses pengajaran praktik industri secara dekat, mempunyai pengetahuan di bidang industri dengan model CIPP (context, input, process, output). Langkah-langkah penelitian yang ditempuh adalah melakukan studi pendahuluan, pengumpulan data, analisis data dan penarikan kesimpulan. Hasil penelitian menunjukan bahwa Evaluasi proses penggunaan dana bantuan Teaching Factory di SMK Jakarta Pusat 1 telah berjalan sesuai dengan Peraturan Kuasa Pengguna Anggaran Satuan Kerja Direktorat Pembinaan Sekolah Menengah Kejuruan Nomor: 09-PS-2017 tentang Petunjuk Pelaksanaan Bantuan Pemerintah Teaching Factory tahun 2017. Adapun dana bantuan Teaching Factory digunakan untuk beberapa hal, seperti; pengembangan Non-Fisik (penyusunan perangkat-perangkat Tefa, pengembangan SDM, koordinasi dengan instansi/industri terkait, analisa dan penetapan kebutuhan bahan sarpras dan pengembangan Fisik (pengadaan bahan praktek, pengadaan dan perbaikan peralatan, rehabilitasi bengkel/lab atau ruang penunjang praktek dan kegiatan fisik terkait lainnya).
\end{abstract}

\section{Kata kunci: Evaluasi Program Bantuan, Teaching Factory}

\begin{abstract}
Teaching Factory is an approach vocational education where learning process are designed such as work aimed at modernizing in teaching process of industrial practices, with knowledge in the industrial sector using CIPP model (context, input, process, output). The research steps taken were conducting a preliminary study, collect the data with data analysis and drawing conclusions. The results showed that the evaluation of the process of using Teaching Factory aid funds in SMK Jakarta Pusat 1 Vocational Schools had been running in accordance with the Regulation of the Budget User Authorization for the Directorate of Vocational High School Development Number: 09-PS-2017 concerning Instructions for the Implementation of Government Assistance for Teaching Factory in 2017. Teaching Factory assistance is used for several things, such as; NonPhysical development (compilation of TeFa equipment, human resource development, coordination with related agencies/industry, analysis and determination of infrastructure needs and Physical development (procurement of practice materials, procurement and
\end{abstract}


repair of equipment, rehabilitation of workshops/labs or practice support rooms) and other related physical activities).

\section{Keywords: : Assistance Program Evaluation, Teaching Factory}

\section{INTRODUCTION}

Berdasarkan Intruksi Presiden Republik Indonesia Nomor 9 Tahun 2016 tentang revitalisasi sekolah menengah kejuruan dalam rangka peningkatan kualitas dan sumber daya manusia (SDM) di Indonesia. Dalam intruksi presiden kepada menteri pendidikan dan kebudayaan yaitu membuat peta jalan pengembangan SMK dan menyempurnakan serta menyelaraskan kurikulum SMK. Dilakukan dengan kompetensi sesuai kebutuhan pengguna lulusan (link and match). Dan dari lanjutan intruksi presiden kepada menteri perindustrian dan BUMN salah satunya mendorong industri, BUMN juga memberikan dukungan dalam pengembangan Teaching Factory dan infrastruktur. Teaching Factory berfokus pada integrasi industri dan akademis, melalui adaptasi baru dengan kurikulum pengajaran/pelatihan, dicapai dengan penyebaran berbasis tekhnologi (Mavrikios et al., 2018). Teaching Factory muncul sebagai pendekatan baru untuk mengatasi tantangan dan kekurangan melalui penggunaan lebih luas dari metode pembelajaran (Mavrikios et al., 2019). Direktorat pembinaan sekolah menengah kejuruan dalam rangka menyiapkan tenaga terampil, kompeten, dan siap kerja dengan mengembangkan model pembelajaran Teaching Factory. Tahap akhir dari Teaching Factory berupa produk (Mourtzis et al., 2018). Dalam proses perancangan dan penerapan Teaching Factory diwajibkan melibatkan kemitraan dunia usaha tau dunia industri sekitar SMK, untuk membuat lulusannya dapat memenuhi syarat dan kriteria kerja yang dikehendaki oleh dunia usaha atau dunia industri.

Program Teaching Factory adalah kombinasi pembelajaran dari Competency Based Learning dan Production Based Training, dengan maksud bahwa keahlian atau keterampilan dirancang berdasarkan prosedur kerja yang nyata dan hasil produk yang memiliki standar memenuhi persyaratan pasar atau konsumen. Teaching Factory adalah sebuah konsep paradigm pendidikan fanufaktur dalam skema baru dengan peningkatan efisiensi, dalam hal pembelajaran yang mengandalkan aplikasi praktis (Stavropoulos et al., 2018). Dalam proses implementasi program Teaching Factory adalah integrasi konsep bisnis dan pendidikan yang profesional sesuai dengan kompetensi dalam bidangnya. Model pembelajaran Teaching Factory merupakan bagian dari pelaksanaan kurikulum 2013 yang diharapkan dapat mendukung terbentuknya tamatan SMK sesuai kualifikasi dunia usaha maupun dunia industri serta pengguna lainnya. Pada pelaksanaan mengacu pada Standar Nasional Pendidikan (SNP) yang meliputi adalah standar kompetensi lulusan, standar isi, standar proses, dan standar penilaian. Pengayaan atas standar yang ditetapkan.

Pada penelitian ini bertujuan untuk mengungkapkan pelaksanaan Teaching Factory menggunakan model evaluasi yaitu, (a) Context, yang meliputi visi dan misi serta tujuan bidang studi keahlian, kebijakan pemerintah, kebutuhan masyarakat dan kebutuhan dunia kerja; (b) Input, meliputi dukungan sumber daya manusia yaitu guru, peserta didik dan pihak yang lain dalam pelaksanaan Teaching Factory di sekolah yang sesuai dengan standar operasional sistem; (c) Process, yang meliputi pelaksanaan pembelajran Teaching Factory, kemampuan guru dalam memberikan bimbingan kepada peserta didik dalam 
pelaksanaan program; (d) Product, meliputi produk dengan kebutuhan pasar atau konsumen yang sesuai dengan di pasaran dan performansinya.

Menurut (Sudiyanto, 2011) dalam penelitiannya menyatakan bahwa Teaching Factory merupakan kegiatan mengajar oleh siswa yang melakukan kegiatan produktif dalam bentuk produk atau layanan lingkungan sekolah. Sedangkan menurut Moerwismadhi (2009) mengungkapkan Teaching Factory merupakan sekolah yang melakukan kegiatan produksi atau layanan yang merupakan bagian dari proses belajar mengajar. Kemudian sekolah juga harus memiliki pabrik, bengkel, atau kegiatan pembelajaran kewirausahaan lainnya. Menurut Direktorat Pembinaan Sekolah Menengah Kejuruan (PSMK, 2016) banyak institusi pendidikan berusaha untuk membawa praktik pendidikan dekat dengan industri. Oleh karena itu, diperlukan pengembangan model pembelajaran Teaching Factory dilihat dari berbagai konsep dan teori pembelajaran. Menurut Amar, Hidayat, \& Suherman (2019) penerapan pembelajaran Teaching Factory dimana suasana suasana proses pembelajarannya dirancang seperti dunia kerja yang sebenarnya sehingga Teaching Factory telah menjadi suatu pendekatan baru untuk pendidikan kejuruan dengan tujuan yaitu, memodernisasi proses pengajaran dengan membawa kepada praktik industri secara dekat, mengungkit pengetahuan industri melalui pengetahuan baru, dan mendukung transisi dari manual menuju cara bekerja otomatis dan mengurangi kesenjangan.

Perkembangan industri didukung oleh penelitian dan pengembangan, sistem manajemen berbasis ICT, kompetensi sumber daya manusia, serta sistem pemasaran global. Hal ini semata-mata hanya mempertahankan dan menenangkan dalam persaingan bisnis kelas dunia. Terdapat faktor yang paling strategis bagi industri adalah tersedianya keahlian pada sumber daya manusia yang mampu mengadaptasi perkembangan teknologi. Dengan hal tersebut lahirnya Teaching Factory bertolak dari hasil pemikiran para pengajar dilingkungan The University of Puerto Rico-Mayagliez dan The Univesity of Washington (Lamancusa, Castro, 1995). Dalam pemikiran para ahli tersebut menyangkut gagasan adanya revilitasi dan rekognisi di lingkungan laboraturium secara kreatif. Penerapan Teaching Factory merupakan wujud dari salah satu misi Disrektorat SMK yaitu memperdayakan SMK untuk mengembangkan kerjasama antar industri, LPMP, dan berbagai lembaga terkait. Pendidikan yang berkualitas di era sekarang ini merupakan faktor penentu dalam menghasilkan suatu masyarakat yang memiliki kompetensi untuk dapat memasuki bidang pekerjaan yang makin kompetitif akibat perkembangan dunia yang semakin global. Kualitas pendidikan sangatlah penting untuk tongkak dasar kemajuan suatu bangsa dalam memajukan sumber daya manusia dan kemajuan pembangunan nasional.

Evaluasi merupakan tindakan untuk mengumpulkan informasi tentang suatu kasus, dan kemudian menggunakan informasi itu untuk menentukan alternatif yang tepat dalam pengambilan keputusan (Suharsimi, 2014). Selanjutnya menurut Wakhinuddin (2009) menyatakan evaluasi adalah kata evaluasi berasl dari bahasa inggris yaitu "evaluation" yang berarti penilaian atau penaksiran, pengertian istilah evaluasi adalah tindakan terencana untuk mengetahui keadaan objek dengan menggunakan alat, dan hasilnya dibandingkan dengan kriteria untuk mencapai kesimpulan. Wakhinuddin (2009) juga menyatakan bahwa model CIPP menyediakan format evaluasi komprehensif pada setiap tahap evaluasi, khususnya konteks, input, proses dan tahapan produk. Penilaian dengan 
menggunakan model CIPP ini pada prinsipnya mendukung proses pengambilan keputusan dengan menawarkan pilihan dan konsekuensi alternatif (Sukardi, 2008).

\section{METHOD}

Penelitian ini merupakan penelitian observasi dan wawancara yang mengikuti kerangka teori untuk mengevaluasi pelaksanaan program bantuan Teaching Factory di SMK Jakarta Pusat 1. Melalui teknik observasi, peneliti melihat langsung yang akan diteliti mengenai Program Bantuan Pelaksanaan Teaching Factory dari Direktorat Pembinaan Sekolah Menengah Kejuruan (SMK) tahun anggaran 2017 di SMK Jakarta Pusat 1, observasi dilakukan secara tidak langsung. Teknik wawancara, memungkinkan peneliti untuk menggali lebih dalam aktivitas, pengalaman dan pendapat partisipan dengan bahasanya sendiri. Teknik pengumpulan data melalui wawancara dimulai dengan membuat pedoman wawancara kemudian memberikan instrument kepada subjek yang sifatnya mengajukan pertanyaan secara lisan dan akan dijawab secara lisan juga.

Penelitian ini menggunakan model CIPP (Context, Input, Process, Product), dengan pendekatan kualitatif deskriptif. Terdapat empat aspek evaluasi dalam model CIPP, yaitu evaluasi context yang meliputi latar belakang diberikannya program pelaksanaan Teaching Factory di tahun anggaran 2017, evaluasi input yang meliputi sarana/ bahan/ sumber daya yang mendukung terlaksananya bantuan tersebut, evaluasi process yaitu evaluasi pelaksanaan kegiatan program Teaching Factory di tahun pelajaran 2017/2018 dan keberlanjutan pelaksanaan program di tahun pelajaran 2018/2019, evaluasi product yaitu evaluasi hasil dari pelaksanaan pelaksanaan program bantuan di tahun anggaran 2017 dan keberlanjutannya di tahun pelajaran 2018/2019.

Metode evaluasi yang digunakan dalam penelitian ini adalah metode evaluatif. Metode penelitian evaluatif dipilih dengan pertimbangan bahwa penelitian difokuskan pada evaluasi pelaksanaan bantuan pelaksanaan Teaching Factory yang diberikan kepada SMK Jakarta Pusat 1 tahun anggaran 2017, apakah program tersebut berjalan pada tahun pelajaran 2018/2019 yang meliputi konteks, input, proses dan produk. Penelitian ini melibatkan populasi berjumlah 201 orang dengan perincian yaitu, Kepala Sekolah, Wakil Kepala Sekolah, Ketua Kompetensi Keahlian, Guru Kompetensi Keahlian, Dunia Usaha/Industri, Asesor Lembaga Sertifikasi Profesi (LSP) dan Siswa di SMK Jakarta Pusat 1.

Tabel 1. Data Partisipan

\begin{tabular}{lc}
\hline \multicolumn{1}{c}{ JABATAN } & KET \\
\hline Pengawas SMK Jakarta Pusat 1 & $1 \mathrm{org}$ \\
Kepala sekolah & $1 \mathrm{org}$ \\
Wakil Kepala Sekolah/Guru Mapel Kejuruan & $1 \mathrm{org}$ \\
Wakil Kepala Sekolah/Guru Mapel Kejuruan/Asesor Akuntansi & $1 \mathrm{org}$ \\
Ketua Kompetensi Keahlian BDP/Asesor Pemasaran & $1 \mathrm{org}$ \\
Ketua Kompetensi Keahlian RPL & $1 \mathrm{org}$ \\
Guru Mapel Kejuruan/Asesor Administrasi Perkantoran & $1 \mathrm{org}$ \\
Ketua Kompetensi Keahlian AKL/Guru Kejuruan/Asesor Akuntansi & $1 \mathrm{org}$ \\
Ketua Kompetensi Keahlian OTKP/Guru Kejuruan/Asesor Adm & $1 \mathrm{org}$ \\
$\begin{array}{l}\text { Perkantoran } \\
\text { Guru Mapel Kejuruan }\end{array}$ & $6 \mathrm{org}$ \\
Siswa kelas 11 AKL & 186 org \\
\hline
\end{tabular}


AKSARA: Jurnal Ilmu Pendidikan Nonformal

P-ISSN 2407-8018 E-ISSN 2721-7310 DOI prefix $\underline{10.37905}$

Volume 07, Issue 03 September 2021

http://ejurnal.pps.ung.ac.id/index.php/Aksara

\section{RESULTS AND DISCUSSION}

Penelitian ini menghasilkan tiga tema temuan, antara lain (1) Penggunaan dana bantuan pada tangal 10 November 2017; (2) Bergesernya jadwal kegiatan pembelajaran Teaching Factory; dan (3) Implementasi dan evaluasi penggunaan dana kegiatan Teaching Factory.

\section{Penggunaan Dana Bantuan pada Tangal 10 November 2017}

SMK Jakarta Pusat 1 mengajukan bantuan pengembangan Teaching Factory tahun 2017 bertujuan untuk meningkatkan kompetensi guru yang berimbas kepada kompetensi siswa hasil lulusan meningkat. Adapun maksud TeFa atau Teaching Factory adalah kegiatan pembelajaran yang memproduksi barang dan/jasa yang pelaksanaannya merupakan bagian integral dari proses pembelajaran di SMK dengan standar kerja dan SOP dari dunia industri dengan tujuan untuk meningkatkan kompetensi Peserta Didik dan Pendidik. SMK Jakarta Pusat 1 berpedoman kepada Peraturan Kuasa Pengguna Anggaran Satuan Kerja Direktorat Pembinaan Sekolah Menengah Kejuruan Nomor : 09-PS-2017 tentang Petunjuk Pelaksanaan Bantuan Pemerintah Teaching Factory tahun 2017. Kegiatan pembelajaran Teching Factory di 1 dimulai dari penyusunan matrik produk, analisis kondisi dan potensi, menentukan prioritas usaha, melakukan analisis kurikulum berbasis TeFa dari setiap kompetensi keahlian, selanjutnya disusun Rencana Pelaksanaan Pembelajaran (RPP). Monitoring dan evaluasi dilaksanakan oleh petugas Direktorat Pembinaan Sekolah Menengah Kejuruan pada tanggal 10 November 2017.

\section{Bergesernya Jadwal Kegiatan Pembelajaran TeFa}

Pelaksanaan Teaching Factory atau TeFa SMK Jakarta Pusat 1 efektif diberlakukan mulai semester genap tahun pelajaran 2017/2018 menggunakan waktu efektif 18 minggu. Namun, dalam pelaksanaan kegiatan TeFa bergeser dari yang seharusnya selesai di minggu ke-2 bulan November 2017, menjadi minggu ke-4 bulan Desember 2018. Implementasi pembelajaran $\mathrm{TeFa}$ baru terlaksana di Semester Genap tahun pelajaran 2017/2018. Bergesernya jadwal TeFa disebabkan karena banyaknya persiapan yang harus dilakukan untuk memulai kegiatan.

\section{Implementasi dan Evaluasi Penggunaan Dana Kegiatan Teaching Factory}

Pembelajaran berbasis Teaching Factory (Product Based Education Training). Untuk mendukung penyelenggaraan Teaching Factory diperlukan sumber daya manusia (guru, paket keahlian dan staf), sarana dan prasarana, mitra dudi yang mendukung penyelenggaraan TeFa di SMK Jakarta Pusat 1, dalam evaluasi input dibutuhkan pengetahuan mengenai kondisi setiap kompetensi kejuruan, produk/jasa apa yang akan dikembangkan, industri mana yang akan berkolaborasi dalam melaksanakan program $\mathrm{TeFa}$, sarana dan prasarana apa yang dibutuhkan dan, setelah mengetahui kondisi setiap kompetensi yang akan dikembangkan, selanjutnya menentukan rencana pengembangan fisik maupun non fisik.

Evaluasi proses penggunaan dana bantuan Teaching Factory di SMK Jakarta Pusat 1 telah berjalan sesuai dengan Peraturan Kuasa Pengguna Anggaran Satuan Kerja Direktorat Pembinaan Sekolah Menengah Kejuruan Nomor: 09-PS-2017 tentang Petunjuk Pelaksanaan Bantuan Pemerintah Teaching Factory tahun 2017. Adapun dana bantuan Teaching Factory digunakan untuk beberapa hal, seperti; pengembangan Non- 
Fisik (penyusunan perangkat-perangkat TeFa, pengembangan SDM, koordinasi dengan instansi/industry terkait, analisa dan penetapan kebutuhan bahan sarpras) dan pengembangan Fisik (pengadaan bahan praktek, pengadaan dan perbaikan peralatan, rehabilitasi bengkel/lab atau ruang penunjang praktek, koordinasi dengan Industri terkait, penyempurnaan tata letak peralatan, dan kegiatan fisik terkait lainnya). Terlaksananya kegiatan dengan baik telah sesuai dengan model CIPP, evaluasi program diarahkan pada seberapa jauh kegiatan yang dilaksanakan didalam program sudah terlaksana sesuai dengan rencana (Suharsimi, 2014).

SMK Jakarta Pusat 1 dalam melaksanakan bantuan yang telah diterima dari Direktorat Pembinaan Sekolah Menengah Kejuruan sebesar Rp. 250.000.000,00 (dua ratus lima puluh juta rupiah) telah digunakan untuk kegiatan-kegiatan yang tertuang dalam petunjuk teknis dari Direktorat Pembinaan Sekolah Menengah Kejuruan, pencatatan keuangan telah disusun berdasarakan petunjuk teknis, dan kegiatan pembelajaran pada tahun pelajaran 2017/2018 untuk mata pelajaran kejuruan sudah menggunakan rencana pelaksanaan pembelajaran dan melaksanakan pembelajarannya sesuai dengan model pembelajaran PBET (Product Based Education Training) dan telah di monitoring pelaksanaannya, baik dari Direktorat PSMK sendiri selaku pemberi bantuan, maupun dari Pengawas Sekolah Menengah Kejuruan Suku Dinas Pendidikan Wilayah 1 Kota Administrasi Jakarta Pusat.

\section{CONCLUSION}

Hasil dari evaluasi input yang penulis laksanakan dapat disimpulkan bahwa bantuan pelaksanaan Teaching Factory bermuara kepada bagaimana sekolah dalam hal ini bapak/ibu guru dalam kegiatan pembelajarannya melaksanakan metode Pembelajaran berbasis Teaching Factory (Product Based Education Training). Untuk mendukung penyelenggaraan Teaching Factory diperlukan sumber daya manusia (guru, paket keahlian dan staf), sarana dan prasarana, mitra dudi yang mendukung penyelenggaraan TeFa di SMK Jakarta Pusat 1, dalam evaluasi input dibutuhkan pengetahuan mengenai kondisi setiap kompetensi kejuruan, produk/jasa apa yang akan dikembangkan, industri mana yang akan berkolaborasi dalam melaksanakan program TeFa, sarana dan prasarana apa yang dibutuhkan dan, setelah mengetahui kondisi setiap kompetensi yang akan dikembangkan, selanjutnya menentukan rencana pengembangan fisik maupun non fisik.

Dana bantuan Teaching Factory yang telah diterima tahun 2017, tentunya program Teaching Factory tidak hanya dilaksanakan pada tahun tersebut, setiap tahun ada keberlangsungan, untuk itu diperlukan kebutuhan dana dari internal sekolah maupun dana dari pemerintah (Bantuan Operasional Sekolah) yang dialokasikan untuk memelihara kompetensi guru dan memeliharan sarana dan prasarana pembelajaran.

\section{REFERENCES}

F.Amar, A., Hidayat, D., \& Suherman, A. (2019). Penerapan Model Pembelajaran Teaching Factory 6 Langkah (Model TF-6M) Untuk Meningkatkan Motivasi Berprestasi Siswa dI SMK. Journal of Mechanical Engineering Education. https://docplayer.info/38002134-Penerapan-model-pembelajaran-teaching-factory6-langkah-model-tf-6m-untuk-meningkatkan-motivasi-berprestasi-siswa-dismk.html.

Lamancusa, J., Zayas-Castro, \& R. (1995). The Learn-ing Factory -- A New Approach to 
Integrating De-sign and Manufacturing into Engineering Curricu.

Mavrikios, D., Georgoulias, K., \& Chryssolouris, G. (2018). The Teaching Factory Paradigm: Developments and Outlook. Procedia Manufacturing, 23(2017), 1-6. https://doi.org/10.1016/j.promfg.2018.04.029

Mavrikios, D., Georgoulias, K., \& Chryssolouris, G. (2019). The Teaching Factory Network: A new collaborative paradigm for manufacturing education. Procedia Manufacturing, 31, 398-403. https://doi.org/10.1016/j.promfg.2019.03.062

Moerwismadhi. (2009). Teaching"factory suatu pendekatan dalam pendidikan vokasi yang memberikan pengalaman ke arah"pengembangan technopreneurship.

Mourtzis, D., Vlachou, E., Dimitrakopoulos, G., \& Zogopoulos, V. (2018). CyberPhysical Systems and Education 4.0 -The Teaching Factory 4.0 Concept. Procedia Manufacturing, 23(2017), 129-134. https://doi.org/10.1016/j.promfg.2018.04.005

PSMK, D. (2016). Grand"Design Pengembangan Factory dan Technopark"di SMK. Jakarta: "Direktorat Pembinaan Sekolah Menengah"Kejuruan.

Stavropoulos, P., Bikas, H., \& Mourtzis, D. (2018). Collaborative Machine Tool design: The Teaching Factory paradigm. Procedia Manufacturing, 23(2017), 123-128. https://doi.org/10.1016/j.promfg.2018.04.004

Sudiyanto, G.S., Yoga, S., I. (n.d.). Teaching Factory di SMK ST. Mikael Surakarta. Fakultas Teknik Universitas Negeri Jogyakarta.

Suharsimi. (2014). Evaluasi Program Pendidikan. Jakarta: PT Bumi Aksara.

Sukardi. (2008). Evaluasi Pendiidkan Prinsip \& Operasionalnya. Jakarta Timur: Bumi Aksara.

Wakhinuddin. (2009). Evaluasi Program. Padang: UNP Press. 
AKSARA: Jurnal Ilmu Pendidikan Nonformal

P-ISSN 2407-8018 E-ISSN 2721-7310 DOI prefix 10.37905

Volume 07, Issue 03 September 2021

http://ejurnal.pps.ung.ac.id/index.php/Aksara

966 AKSARA: Jurnal Ilmu Pendidikan Nonformal 